\title{
The Faroe Islands and the Arctic: Genesis of a Strategy
}

\author{
Alyson J.K. Bailes, Adjunct Professor, University of Iceland and Beinta í \\ Jákupsstovu, Associate Professor in Political Science at Molde University \\ College, Norway
}

\begin{abstract}
The Faroe Islands, a non-sovereign nation within the Kingdom of Denmark, have become the latest actors in the extended Arctic region to prepare their own strategy on Arctic affairs. A working group report of April 2013 predicts peaceful Arctic development that could bring profit for the Faroes but also new challenges notably in the field of civil security. Its detailed sections contain recommendations on economic opportunities especially linked with increased shipping and fisheries; research and education; the environment; and maritime safety and emergency response. The report is a professional product, reflecting years of Faroese engagement in Arctic research, fisheries, and international cooperation in the Arctic Council and elsewhere. It shows how Arctic considerations are pushing the Faroes towards acquiring more independent capacities, including new legal rights and institutional participation, given their already extensive relevant competences and the differences between their needs and Denmark's. Further, some features of the Faroes' response to the challenges facing them mirror the finds of 'small state' studies and confirm that non-sovereign entities having reached a certain level of autonomy can (mutatis mutandis) have similar external agendas, and seek similar solutions, to states of comparable size. While the report's conclusions have already been accepted by the Faroese Parliament, some question-marks remain over Faroese capacity to realize its potentially costly recommendations.
\end{abstract}

Keywords: Small states; autonomous territories; Arctic; Nordic region; strategy making.

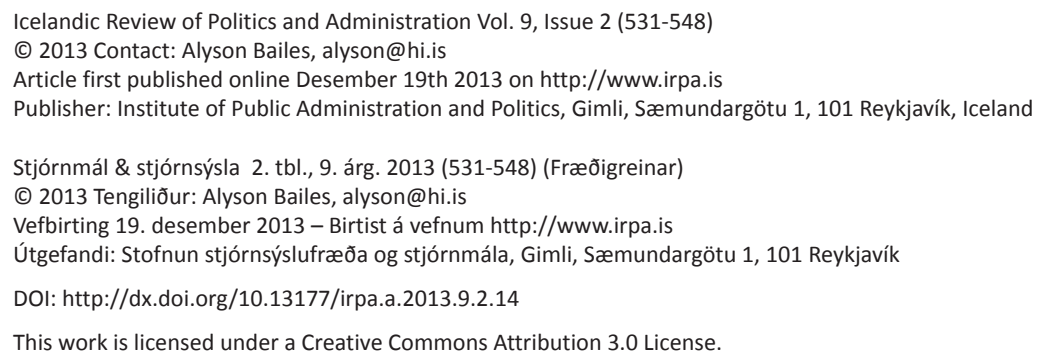




\section{STJÓRNSÝSLA}

\section{Introduction and Aims}

The evidence of accelerating climate change in the world's Arctic (or 'High North') regions, and the expected impacts on human activity as well as nature, have led all states surrounding the North Pole to publish Arctic 'strategy' documents in recent years (Bailes and Heininen 2012). These official papers convey each country's judgement on the issues likely to arise, typically covering some mixture of strategic, economic, environmental and human/societal topics. They discuss the implications for national interests and express preferences on the principles, methods and institutional frameworks for addressing the challenges involved. They are addressed equally to internal and external audiences, seeking at the same time to foster internal solidarity, confidence and coordination, and to gain external understanding and respect.

Denmark was one of the first to issue such a strategy, in 2008, and followed it with an updated version in 2011 (Denmark et al. 2011). While the metropolitan territory of Denmark is the most Southerly of Nordic states, lying on the European continent well below the Arctic Circle, the Danish realm includes the self-governing nations of Greenland and the Faroe Islands which have acquired extensive home-rule powers since World War Two. The 2011 Danish strategy was explicitly designed to speak for these two entities as well and was co-signed by their leaders. It conveyed a peaceful and constructive vision of Arctic development, while signaling resolve to uphold the appearance and substance of sovereignty over all parts of the Danish realm. In terms of international governance it commended cooperation through the International Maritime Organization (IMO); the Arctic Council, but also the inner group of five littoral states; ${ }^{1}$ the European Union especially as a developmental partner for Greenland; Nordic and West Nordic institutions, and the US and Canada bilaterally.

The Faroese Home Rule Government had begun separately to review their place in Arctic cooperation as early as 2009, following the first Danish strategy document and shortly after establishing their own Ministry of Foreign Affairs (Ólavsdóttir et al. 2011). An internal report of 2010 (Uttanríkisráðið 2010) concluded with a recommendation to set up a commission on the topic; and as a first step, a revised version of this report was published for a wider Faroese public in 2011 (Uttanríkisráðið 2011). The joint Kingdom of Denmark strategy produced in the latter year did not dispose of the issue, since the Faroese and Greenlanders both felt that the drafting process and limited time for consultation had not allowed this document fully to reflect their concerns and prospective roles. In Spring 2012, therefore, the Faroese Home Rule Government launched a more formal and comprehensive enquiry into Arctic developments, analogous to the strategy-making processes of other member-states in the Arctic Council. As recommended in the first report (Uttanríkisráðið 2010, p.19), a working party ${ }^{2}$ was set up for the purpose and consequently supplemented by presentations and advice from foreign specialists.

The resulting report, 'The Faroe Islands - a Nation in the Arctic' (Prime Minister's Office 2013) was released in Faroese in April 2013 and in English in August the same year. Its rationale was described thus (p.5): 


\section{STJÓRNMÁL \& \\ STJÓRNSÝSLA}

Large parts of the joint strategy relate in general to areas for which the Faroe Islands have exclusive competence. The Government of the Faroes has therefore considered it necessary to produce a dedicated national assessment with a focus on areas of particular relevance and interest for the Faroe Islands.

The areas seen as of particular relevance were reflected in the report's main sections: economic opportunities especially linked with increased shipping through the Northern Sea Route (ie, over Russia); fisheries; research and education; the environment; and maritime safety and emergency response. On each of these, the report - which in general was very well structured - formulated a number of precise recommendations. The Introduction proposed that the latter be debated in the Faroese parliament (Løgting) with a view to deciding some initial priorities; and on 26 November 2013 the Løgting duly addressed the report. The analysis and recommendations were welcomed and accepted by all political parties, albeit with a shade of concern over resource implications, and it was agreed to set up a working group with representatives of all relevant government ministries to develop an action plan. The latter will define the associated responsibilities, costs and work-load for each aspect of implementation and will be submitted to the Faroese Government for final approval.

The primary purpose of this article is to provide an exegesis of the Faroese report and to discuss its background and implications, both as an additional or alternative 'take' on the Arctic agenda as such, and as a reflection of the current state of play in Faroese policy development and the Faroes/Denmark relationship. The next section (2) will introduce the general vision and tone of the Faroese document, and consider where it falls into the spectrum of other actors' 'strategies' and their views on Arctic governance. Section 3 sets the report in the context of the Faroese national background and constitutional developments. Section 4 presents and comments on the findings of the report in its five main thematic divisions. Section 5 offers a final assessment and overview.

The Faroes' Arctic predicament may also, however, be viewed in a broader conceptual framework as a potential case for the application of 'small state' theories. ${ }^{3}$ These theories have, naturally enough, focused since their inception (in the post-World War Two period) on sovereign entities, including 'micro-states' that enjoy national sovereignty while lacking some significant practical features of a self-supporting polity (Simpson 2014 (forthcoming)). However, when an autonomous territory has competences that require it to be active in its own right in at least some external relationships (eg, to conduct fishery negotiations), it can be argued to share in the experiences of state actors of similar size at least to that extent, and mutatis mutandis. Further, while its strategic protection should normally come from the state of which it forms a part, its location may confront it with a different combination of external challenges, for at least some of which it needs to consider its own solutions. A Nordic-funded research project on 'Nordic and Baltic Small States', led by the University of Iceland's Centre for Small State Studies in 2012-13, included partners from the Faroes and Greenland and found that on 
the broad issues addressed - economics, security and identity - the concerns, opportunities and policy preferences of these two non-sovereign actors often fitted well within the spectrum of the five Nordic and three Baltic states' experience. ${ }^{4}$

If the starting-point of the Faroe Islands, facing their Arctic agenda, is viewed as at least partly analogous to that of a 'small state', what issues might arise and what typical features should one look for? The small state literature has itself evolved since early days when - echoing the prevailing theory of realism - its focus was on small actors' lack of traditional (military and economic ) power, and hence their vulnerability to aggression or blackmail (Keohane 1969; Vital 1967; Handel 1981; Bartmann 1999)). Small states' options for self-protection were seen as limited to sheltering behind a larger state ('bandwaggoning'), or trying to 'balance' the source(s) of threat by joining with a number of like-minded partners. Later as liberal internationalist, institutionalist, and social constructivist perspectives were added, ${ }^{5}$ it became relevant to ask how far international organizations, at global and regional level, might serve similar purposes for a small state, and what the state would need to do to gain full advantage from them at bearable cost (Wivel 2005; Bailes and Thorhallsson 2012).

Most recently, a stronger focus has been added on the economic vulnerabilities of small states including their narrow productive base and dependence on imports (Katzenstein 1984, 1985; Briguglio, Cordina and Kisanga 2006). While no single or complete remedy exists, prescriptions for small entities facing such challenges typically call for conscious strategy-making based on sound internal consensus; identification of a limited set of key issues and interests; prudence and diversification in key areas of dependence, and tactical skill and flexibility in making the most of each external relationship (e.g. Bailes and Thorhallsson 2011; Ólavsdóttir et al. 2011; Bailes, Thorhallsson and Rickli 2014 (forthcoming)). Small states can also profit by deliberately creating and promoting a 'brand image', which may or may not reflect aspects of their actual identity and practices (Stringer 2013). This small-state analytical framework will be kept in view during the following sections: and the conclusions in section 5 will ask (among other things) how well the Faroe Islands' definition of, and approach to handling, their Arctic agenda accords with the corresponding small-state models.

\section{Defining the Arctic Agenda}

The Faroese working party heard evidence from experts taking varying views on the Arctic future, ranging from alarmism over potential conflict to scepticism about the likely realistic pace of development. Page 9 of the report comes down firmly against an alarmist, or military-focused, vision:

Today few people fear military disputes between the Arctic coastal states. Instead, the military bases in the Arctic territories are considered an integral part of the emergency and rescue infrastructure in the area... The real safety and security issues in the area concern the consequences of climate change and the risk of accidents that come from the increase in commercial activities in the area. 
This view is underpinned, inter alia, by noting that most prospective new oil/gas resources lie within states' clearly established jurisdictions; that the Arctic powers have built up constructive cooperation through the Arctic Council and more specialized groups; and that at Ilulissat in 2008 the littoral states pledged themselves to a peaceful and law-based approach. ${ }^{6}$ Further, the report tackles head-on the view of some observers that Arctic governance is inadequate and should be covered by an Antarctic-type general treaty (p.9):

The people in the Arctic do not agree that the Arctic needs a similar international treaty. There is a fundamental difference between the Arctic and Antarctica.... The Arctic countries are perfectly capable of managing development and cooperation in the Arctic area in a sensible and peaceful manner and in accordance with relevant international treaties and principles.

In taking this non-sensational view, in focusing on practical economic issues, and in limiting discussion of security topics essentially to accidents and natural hazards, the Faroese report aligns itself both with the spirit of other European Arctic strategies and with the typical approach of entities that carry no sovereign responsibility for defending High Northern frontiers. Finland and Sweden, which today have no coastlines on the Arctic seas, are good examples of the latter and their Arctic strategies (Bailes and Heininen 2012: 63-70 and 80-3) resemble the Faroese analysis in devoting much of their effort to identifying specific economic opportunities. At the same time, while reporting the optimum assessments of Arctic capacity eg in oil and gas, the Faroese study is not over-sanguine in presenting the cost-benefit balance of climate change. It recognizes the damage and disruption brought by the process itself, and gives detailed attention to the new accident and pollution risks associated with increased resource extraction and shipping. It does not, like the Norwegian and Russian strategies in particular (Bailes and Heininen 2012: 30-5 and 42-51), present Arctic development as a deciding factor in the whole nation's future and thus, a top strategic imperative. Rather, new Arctic opportunities are seen as growing out of the Faroes' established profile and providing supplements to a consistent, prudent, overall development policy.

In this and other respects, the Arctic strategy of Iceland - smallest of the Nordic states - provides an interesting parallel. It is unique (thus far) in having been enacted by the national parliament rather than published by a government (Bailes and Heininen 2012:71-9; Althingi 2011), although closely following recommendations made in 2010 by the then Foreign Minister, Össur Skarphéðinsson. The Faroese procedure, inviting the Løgting to decide the priorities that will subsequently guide the government, shows a similar regard for democratic control - linked with the wish, as the report itself explains, to get all relevant state and non-state forces aligned in support of the strategy. The need to mobilize all possible national resources for such ends is felt especially in nations as small as Iceland with its 320,000 inhabitants and the Faroes with 49,000.

A further 'small-state' feature linking the Icelandic and Faroese strategies is the effort 


\section{STJÓRNSÝSLA}

that such entities, when seeking to influence international processes, must devote not only to defining their goals but also to considering how to get their voices heard. At one level this guides small players to encourage and invest in formal, institutional, law-based approaches where they can hope at least for a seat at the table and a level playing-field for their companies (Bailes 2008 and 2013). At another it makes them very conscious of and sometimes touchy about their status and rights. The principles of Icelandic Arctic policy thus contain almost as many 'procedural' as substantial points, including Iceland's claim to be considered a 'littoral' state and its opposition to the separate meetings of the 'Arctic Five'. How does this compare with the Faroese approach?

The latter case is of course different in that the Faroes do not claim full statehood nor, under the present government, are seeking it (see more on Faroese politics in the next section). But the Faroese report does start with a detailed section on participation in Arctic governance, arguing that the nation both can and should seek representation everywhere that it has a specific point of view and interests to put forward, and where Faroese experts and companies have something to offer. On the issue of Arctic Council representation - which hit the headlines when Greenland boycotted the May 2013 Kiruna Ministerial in protest at the top-table seating arrangements for Denmark ${ }^{7}$ - the report commends the arrangement whereby the Faroes are seated with a separate flag as part of the Danish delegation. It does however call for a more efficient way of involving Faroese personnel in the detailed work of the Arctic Council including the scientific working groups. It stresses the value of the 'West Nordic' framework where the Faroes, Greenland and Iceland meet without a Danish presence, and proposes a joint West Nordic policy approach to the Arctic. ${ }^{8}$ (The Nordic Council and Nordic Council of Ministers already provide for separate Faroese representation at all levels, including on the NCM's Arctic Expert Committee. ${ }^{9}$ ) It suggests that the Faroes seek full membership of the Standing Committee of Parliamentarians of the Arctic Region, a large assembly linked with the Arctic Council. ${ }^{10}$ Almost alone among Arctic strategies, it stresses the value of other non-governmental tools for raising the Faroes' profile including more English-language publications on the topic, and involvement by non-state experts in important conferences and international networks. Intriguingly, in this section and the report generally, Danish help is almost never invoked: only when it comes to dealings with the EU is Copenhagen asked to make sure that the EU institutions are aware of Faroese interests and views. ${ }^{11}$

\section{The Faroese Starting-Point}

The background to the Faroe Islands' Arctic policy may be explored at two levels: that of the nation's Arctic identity or lack of it, and that of politics including the evolving relationship with Denmark. On the first point, even the authors who gave the new Faroese report its title would probably not maintain that the Faroes are 'in' the Arctic in a simple geographical sense. Rather, this cluster of islands with its 49,000 inhabitants, 1400 squares kilometres of land, and a fishery zone of 275,000 sq.km. at sea (based on a 200nautical-mile limit) is normally viewed as a natural feature of the North Atlantic. It lies 
only some $320 \mathrm{~km}$. from the Scottish mainland, and even closer to the Shetland Islands. Yet it occupies what is at present the most active gateway into the Arctic seas; shares key socio-economic features with the recognized 'High Northern' territories; and is politically and institutionally linked with both the states and organizations most prominent in Arctic affairs.

Economically, the Faroese nation depends almost exclusively on fisheries, and Faroese sailors have long experience of navigation in the High North as well as in other oceans. Since the early $20^{\text {th }}$ century, Faroese ships' traditional fishing grounds in Faroese and Icelandic water have been extended to include the Arctic region. Greenland's and Canada's waters and the Barents Sea have become familiar territories for Faroese fishermen, stories are told about their perils, and place-names such as Flemish Cap, Ravnsø and Bjørnøya have entered Faroese children's play vocabulary. To these specific factors may also be added the linguistic, cultural, and general historical commonalities between the people of the Faroes, Iceland, and Western and Northern Norway (Hovgaard et al. 2013; Thor et al. 2012). In sum: the report's placing of the Faroes 'in the Arctic' has a certain factual logic but it may also be understood as a conscious claim to legitimacy as an Arctic actor, of the kind already made by all the other Northern nations publishing such strategies up to now (Bailes and Heininen 2012: 109-10). It might also be seen as a way of further expressing and extending a Faroese 'brand image' (see above, and Stringer 2013) designed to bring attention, sympathy and competitive advantages.

Constitutionally, the Faroes remain part of the Kingdom of Denmark and rely on Copenhagen for their defence, much of their foreign policy and a (now limited) budget subsidy. Under the latest amendment to the islands' home rule status, it is up to the Faroese side to decide whether and when to start proceedings for full independence, but there is no clear political drive for this at present. The latest government, elected in November 2011, has a preponderance of anti-independence politicians who in their early days in office even considered some steps backwards from the current level of autonomy.

Nevertheless, the story of the last decades has been one of gradual extension of self-rule even in the security field and external relations. The Faroese Government is in a process, nearly completed, of taking over the full responsibility for societal (internal and non-military) security, which used to be a shared competence with the Danish authorities (Jákupsstovu and Berg 2012). By now, the police are the only important security service or agency not under local Faroese control. One important stepping-stone was the Faroes' assumption of responsibility for Search and Rescue (SAR) within their sea territory, marked by the establishment of a Maritime Rescue Coordination Centre (MRCC) at Tórshavn in 2002. A new civic security law was passed by the Løgting in May 2012. Given the new Arctic report's heavy emphasis on maritime security, these extended Faroese competences can be seen as one strong factor behind the move towards independent Arctic strategy formation.

In external policy more generally, the Faroes took one important step to establish a distinct status in 1972, when Denmark joined the European Union (EU) and they 


\section{STJÓRNSÝSLA}

declined to do so. Shortly after, the 200-nautical-mile fishing limit was introduced. The Faroes' different relationship with the EU required them to represent their own interests in negotiations with neighbouring nations on fishery rights. Thus, under an understanding with the Danish state, the Faroes have participated in international fishery negotiations and regulations ever since the mid-1970s. The Faroese government has also become an associated and active member of the relevant UN-linked fora, the International Maritime Organization (IMO) being among the most important. On the other hand, Faroese connections with institutions of wider competence have remained generally weak. Denmark is for example a member of NATO and Allied defence guarantees extend to the Faroes, but the latter have no representation of their own at NATO headquarters (and this is probably not the organization most Faroese governments would want to prioritize as a target). The links to the EU, aside from fisheries talks (and disputes), are especially weak. While Greenland as a previous Danish colony has been recognized as one of the Union's OCTs (Overseas Countries and Territories), and Iceland and Norway are members of the European Economic Area (EEA), the Faroes have only gone as far as concluding bilateral trade agreements.

One of the main reasons for the weak formalization of the Faroes' major international relationships - especially with organizations - has been the lack of human resources in the Faroese Government administration up to the present century. In the circumstances, the emphasis placed in the 2000s on strengthening local expertise in foreign policy meant also a substantial shift in focus and priorities. The first separate Faroese Ministry of Foreign Affairs (MFA), as already noted, was established in 2008 (Ólavsdóttir et al. 2011). Despite being merged with the prime minister's office by a decision of the new government in 2012, this ministry has built up a cadre of specialized officials in both the older and younger generations and has grown to be something of a 'state within the state'. The present Office for Foreign Affairs (Uttanríkistænastan) remains a driving force for formalizing and strengthening ties to international organizations and developing different co-operation relationships. There are four Faroese diplomatic delegations working separately from Danish missions in key locations abroad.

Realizing that the Faroese government's ties to the outside world were too loose, and in many cases even non-existent, one of the first tasks the new MFA gave itself in 2008 was to review the nation's existing memberships, the Arctic Council among them. Like Greenland, the Faroe Islands had been a member of the Arctic Council through the Kingdom of Denmark since the Council was established in 1996. The representation is called Denmark/Greenland/Faroe Islands, or DGF. Up to 2004 the Faroes had sent representatives to most Senior Arctic Officials' meetings (SAO) within the Arctic Council but had not given this forum high priority. Since the MFA was established in 2008, the Faroe Islands have participated in all SAO meetings. The MFA also worked to raise awareness of the Arctic Council in other parts of the government, particularly during the Danish chairmanship of the Council in 2009-2011 when the Faroes hosted (in October 2010) one of the two annual Council meetings. It was not difficult to arouse wider Faroese interest, as much of the Arctic cooperation relates to areas (like shipping, 
environment, fisheries and civil security) for which the Faroe Islands now have exclusive competence.

In parallel with this official involvement, Faroese researchers have for decades been active in international research on oceanographic and marine biological changes in the North Atlantic. From 1991 they joined in working groups under the Arctic Environmental Protection Strategy (AEPS), the precursor to the Arctic Council: more specifically in the Arctic Monitoring and Assessment Programme group (AMAP), and from 1994 in the working group on Conservation of Arctic Flora and Fauna (CAFF). When the environmentally-focussed AEPS was converted into the inter-governmental Arctic Council, with a wider agenda, this Faroese participation helped to justify the decision to have the Faroes seated at the Council table within the Danish delegation.

The reasons for the latest surge of Faroese activism on the Arctic are not much different from those impelling Iceland or any other local polity involved. Increasing speculation about the effects of ice melting has promoted interest in new economic possibilities, as more ship traffic passing through Faroese waters to and from the Arctic might open the way for new jobs in support and supply services, and the new biological environment might expand possibilities for fisheries. As already noted, however, natural and human risks also follow with the changed natural environment, making the Faroese nation a potential victim of accidents and pollution events. Local resources for responding are limited to the Faroese Coastguard/SAR service with its two ships and access to a rescue helicopter - which is not always available given the need for maintenance and repair - plus high-speed rescue boats owned by voluntary rescue organizations, but with a limited range. Hitherto, civil as well as territorial security has been served by a vessel of the Danish Royal Navy still patrolling Faroese waters. However, the Kingdom of Denmark's military defences have been going through a re-structuring whereby the two separate Faroese and Greenlandic commands were closed down by October 2012 and replaced by one joint Varnsfalles Arktisk Kommando in Nuuk, Greenland. ${ }^{12}$ Only a handful of liaison personnel have been left in the Faroe Islands. Even if there is scant appetite among the Faroese people for a military establishment of their own, these developments raise questions about rescue and emergency capacity that - as we shall see below - have helped to drive the call for an independent Arctic strategy review, and figure strongly in the resulting report's coverage and conclusions.

\section{The Chosen Dimensions}

As discussed above, the five sub-topics that the Faroese report focuses on are fairly standard for the Arctic 'strategies' both of neighbouring states, and of institutions - like the European Union ${ }^{13}$ - that have addressed the matter. It is understandable that we do not find a section on traditional security threats and the protection of sovereignty; also, that there is no extended discussion of indigenous peoples (though the report elsewhere expresses kinship with them). The pattern of Faroese interests is faithfully represented by the fact that maritime issues including fishing come first. It is also interesting that research and education are given a separate section: this chimes with the general atten- 


\section{STJÓRNSÝSLA}

tion being devoted currently in the Faroes (and also Greenland) to reducing the previous level of dependence on Danish academe.

\section{4.i) Economic Opportunities}

This section (pp. 14-19) covers possible increases in merchant shipping (from the East, over Russia), tourism, sub-sea oil and gas exploitation, on-land mining, and fishing (by others). The focus is on Faroese openings to provide facilities and services, especially in the Greenland/Iceland/Norway maritime area, bearing in mind inter alia the possibility of a rapid rise in economic activity in Greenland and the already strong foothold of Faroese partners in the Greenland market. The idea of siting a major transshipment and service centre for cargo shipping in the Faroes is mooted but discussed in realistic terms. While the report takes a relatively positive view of the speed of development, brushing aside possible environmentalist opposition, it stresses that several others are aiming to harvest the available profits -the report includes a nation-by-nation analysis of such ambitions - and that even Iceland is well ahead of the Faroes in such planning. Another issue is whether the Faroes' actual human potential is being properly 'branded' and recognized. The report quotes the shipping insurance giant Det Norske Veritas as saying that only some 2,000 people alive today may be fully qualified to navigate and work in the Arctic Ocean - and adds the comment that many of them may be Faroese. But many Faroese currently working in the major sectors are doing so for foreign firms, outside their own borders.

The ensuing recommendations are quite general, perhaps because of the diversity of specific opportunities and needs in the branches consulted during the study. The Faroese authorities are called on to establish a strong platform and helpful environment (including tax incentives) for business, i.a. by improving business education, covering Arctic aspects in the plans for a Faroese Export Council, marketing Faroese business to the world, and promoting the Faroes as a 'maritime service centre in the Northeast Atlantic'. The Faroes-Greenland connection must be reinforced, and more done to identify other particularly important partners.

Interestingly, the emphasis on reinforcing the Faroese-Greenland connection rather underplays the already strong presence of Faroese businesspeople, craftsmen and ship's officers, as well as public servants of Faroese origin, in Greenland. The full facts of the Faroese diaspora in Greenland may not be public knowledge in the Faroes, resulting as they do from a multiplicity of private initiatives.

\section{4.ii) Fisheries (pp. 20-23)}

Some $95 \%$ of Faroese exports consist of fish and fish products, making this in effect the sole mainstay of the nation's economy, and explaining why the Faroese so often take a robust stand in fish-related disputes. As the report points out, Faroese vessels already roam far North, approaching the central zone around the North Pole which so far does not fall under any state's jurisdiction - nor under the rules of the North East Atlantic Fisheries Commission, NEAFC. ${ }^{14}$ The need to preserve freedom to take a share of Arc- 


\section{STJÓRNMÁL \\ STJÓRNSÝSLA}

tic fish is treated as almost self-explanatory in the report, not least as some species in the traditional catch may be migrating Northwards (another common feature with Iceland!). The authors therefore come out categorically against a treaty or any other decision that would ban fishing in the (as yet) international waters of the Arctic. ${ }^{15}$ Instead they advocate an international fisheries management body of the NEAFC kind, where the Faroes could take part and uphold its interests. They also recommend staying closely in touch with fisheries research and forecasting work being done in the area, and boosting the resources and activities of the Faroes' own Marine Research Institute, which should share information with Faroese fishermen in the area.

\section{4.iii) Research and Education (pp. 24-26)}

The report notes that the Faroes already make significant contributions to Arctic-related research programmes in several fields of pure and applied science, and such work has brought useful funding to the nation from European, Nordic and other sources. The University of the Faroes, Fróðskapasetur Føroya, is rapidly developing its international networks through schemes including two joint West Nordic Masters' degrees, while the Faroese Centre of Maritime Studies and Engineering has a parallel project with Norwegian, Icelandic and Greenland counterparts. Plans are in hand to make more use of the University of the Arctic network ${ }^{16}$ and to exploit the possibilities of distance learning. However, the report stresses that Faroese resources are necessarily small, and researchers and educators need official support to meet the costs and work burdens of joining networks and attending events abroad. More could also be done to attract foreign experts to the Faroes. The recommendations suggest setting clear functional priorities in research and providing extra official funding, including an information service and pot of funds to help Faroese experts join international projects. Educational ties throughout the Arctic should be fostered and special attention given to distance learning.

\section{4.iv) The Environment (pp. 27-31)}

Given that the direct effects of climate change on the Faroes are likely to be more benign than not, this section focuses on the secondary effects of more human activity in the Arctic and above all, on possible oil and chemical spills in nearby waters. Aside from the direct impact on nature and human settlements, such pollution is an especial threat to small nations whose trade rests on the quality and image of their marine resources, which in the Faroes' case include extensive fish farming. The Faroes have the right national regulations in place and the right international affiliations to set standards, also for any local oil/gas exploitation that may develop; but the problem is with incident response and enforcement capacities. While Faroese institutions do exist with standard procedures for emergency response, capable of handling small-scale local incidents, the report states bluntly that: 'Currently, the Faroe Islands would be unable to assist their neighbouring countries in case of serious oil spills. Moreover the Faroe Islands would not be able to deal with significant oil spills in their own waters without external help due to insufficient equipment'. 
Further, the Faroes currently can only enforce environmental standards on vessels coming within 12 nautical miles of their shores, as the islands have not claimed their own Exclusive Economic Zone (EEZ) under the UN Law of the Seas Convention (UNLOSC). Nor have they used the possibility under UNLOSC to define a Particularly Sensitive Sea Area (PSSA), of the sort that does already stretch south from the Shetland Islands as far as Portugal. There is a risk that ships unwilling to meet PSSA standards will positively favour transiting Faroese waters as a result.

The report is trenchant in its response to these deficits. It points out that while competence for protecting the marine environment was devolved from Denmark to the Faroes in 2003, only one small budget appropriation has been made since. As a first step and at rather modest cost, a 'first aid kit' for responding to oil spills could be added to the present holdings of relevant Faroese equipment (listed in an Annex to the report). A comprehensive oil spill contingency plan should then be developed to deal with all the possible ramifications of such an event, and to equip the Faroes better for international cooperation in the relevant frameworks - which now include the Arctic Council's legally binding agreement on cooperation against major oil spill events, adopted at Kiruna in May 2013 (Arctic Council 2013). Further, a Faroese EEZ should be established to convey greater powers of inspection of foreign vessels, and the creation of a PSSA including the designation of safe shipping lines should be considered. Fulfilment of all these recommendations would add up to a heavy cost both in resources and new responsibilities for the Faroese nation, raising questions about viability that will be returned to later.

\section{4.v) Maritime Safety and Emergency Response (pp. 32-5)}

Once again this section focuses on risks connected with foreign shipping, interestingly implying that the more diverse 'soft' security risks covered in some other nations' Arctic strategies - such as increased frequency of natural disasters, infrastructure breakdowns and insecurity of supply, and societal effects including new health challenges - either do not apply in the Faroes or lie further in the future. As in the case of oil spills, the message is that the Faroese authorities have the basic competence to decide their own approach to maritime accidents and other shipping safety issues, but have not taken either the full legal steps nor the practical ones to make good their responsibility.

The Faroes have their own Maritime Authority and an emergency centre (MRCC/ Tórshavn) for incidents at sea, with access to limited helicopter, lifeboat, and salvage assets as explained in section 3 above. They are party to the Arctic Council's search and rescue cooperation agreement (Arctic Council 2011), and to the inter-Nordic NORDRED framework for rescue services. ${ }^{17}$ Within their competence the Faroes could also expect to benefit from the Nordic countries' recently enhanced 'Haga' framework for civil security cooperation and the mutual assistance ('solidarity') clause adopted by Nordic Ministers in 2011 (Den nordiske solidaritetserklæringen 2011). Finally, the Faroes are an associate member of the IMO, which should allow them i.a. to benefit from the 'Polar Code' on special shipping safety routines for the Arctic, expected to be finalized 
by the IMO in 2014. Yet they have not joined the Paris Memorandum of Understanding (MOU) that would allow them to carry out 'Port State Control' (PSC) inspections of visiting ships. They have not established a legal framework for monitoring and demanding reporting from all vessels in their waters, such as Greenland and Norway have, although the material possibilities for keeping track of shipping do exist.

The report duly recommends that the Faroes accede to the Paris MOU, establish shipping lanes within a PSSA (as above), and create a legally-based control and reporting system for shipping in Faroese waters. Fire safety and evacuation exercises should be organized on board ships. The MRCC/Tórshavn and the relevant agencies in general should take an active part in Nordic and Arctic cooperation programmes. Finally a proposal is made with more general relevance for the Faroes' evolving civil emergency management system (p.35):

The authorities with overall responsibility for contingency planning should activate the Contingency Planning Council so that questions regarding safety and emergency planning in the North Atlantic and the Arctic can be discussed. Contact Element Faroe Islands, the Faroese Maritime Authority, and the Faroese Main Road Authority - all bodies without permanent representation in the Contingency Planning Council - should be represented and consulted when such questions are on the Council's agenda.

If followed, this proposal would have the effect of adding 'meat' to, and materially testing, the civil security planning and coordination systems established by the new Faroese legislation referred to in section 3 above. It would make the Contingency Planning Council a larger and more inclusive body, perhaps creating impetus for other special agencies with practical expertise to be represented there as well.

\section{Final Assessment and Conclusions}

The Faroese team who prepared their nation's first-ever comprehensive and formal Arctic evaluation were able to draw upon a number of models, of growing sophistication, in the Arctic 'strategies' of other nations and institutions. They arguably also benefited from doing this work at a time when the political, academic and media debate on the Arctic had grown more pluralistic and nuanced, and the initial 'hype' regarding both prospective riches and risks of conflict was dying down. ${ }^{18}$ That said, the report published in April 2013 stands out by its professionalism and maturity, reflecting a considerable effort by such a small polity, and showing that a small nation properly aware of its interests and capacities - and willing to make prudent use of foreign expertise - need not come second to any in clarity of analysis. In a short compass (37 pages plus background information and annexes), it provides a great deal of information about the Arctic as well as the Faroes themselves, and offers a full and frank argumentation for its conclusions.

As noted in section 2, the report's judgements on the broad situation are moderate, coloured by common sense and a practical focus on near- and medium-term profits, 
without too much agonizing about sustainability or about aspects of governance (such as military affairs) not relevant to Faroese representation and self-promotion. This approach reflects more general Faroese characteristics - including the limits of autonomy - but it can also be explained in terms of the small-state frame of analysis introduced earlier in this article. Small states have good reason to avoid aggressive and pessimistic statements about their international surroundings, which might turn into self-fulfilling prophecies, and to steer clear of controversies not directly concerning them. Ideally, they should identify a limited range of practical issues on which other states can either look for mutual profit with them, or feel driven to offer them support (Bailes 2008; Bailes et al. 2013). We have seen above how well the Faroese strategy fits this model and in doing so, recalls the corresponding Arctic policy statements by Iceland, Sweden and Finland. Admittedly, this is achieved by deft selection of topics: there is no mention of whaling or current fisheries disputes, and very little about climate change's direct impacts or how to manage it.

In terms of balancing relationships and the use made of multilateral fora, the Faroese report also shows typical small-state features. Its recommendations, if followed, would situate the Faroes comfortably in the Nordic mainstream, but they also steer clear of any stances that would risk isolating the Faroes or conflicting directly with Russian, Canadian, US or even EU policies. While a distant, and sometimes antagonistic, attitude to the EU marks a difference in Faroese strategy from that of most European small states and micro-states (Bailes and Thorhallsson 2012; Simpson 2014 (forthcoming)), the Faroese approach to other organizations directly engaged in Arctic affairs reflects classic smallstate aims: maximum participation and visibility, conscious self-'branding', promotion of national agendas and full exploitation of institutional rights and resources. Last and not least, the very fact of trying to construct such a strategy and to anchor it strongly in non-state constituencies shows Faroese awareness of the need for a small polity to speak with a coherent voice and mobilize all relevant capacities. The inward-looking and outward-looking functions that typically co-exist in other states' Arctic strategies are equally present, and well balanced, in this case.

At the same time, the Faroese case can be used to illustrate the quandaries facing small polities when dealing with agendas as large and complex as the new Arctic one. Very small states may have the best preconditions for democracy because of the close relations between their citizens, but their system capacity will generally be limited when it comes to manpower, and especially the economic power to make expensive investments (Dahl and Tufte 1973). In the present difficult state of Faroese public finances, and amid controversy over conflicting national priorities, it is hard to be optimistic that the full scale of the Arctic report's ambitious proposals on shipping and emergency handling can be realized or even, perhaps, that a rational staged programme will prove feasible. Further, there may be a trap in too easily supposing that a consensus such as that apparently reflected in the report is truly inclusive, or that transparency and mutual knowledge about the activities involved - notably in the civic security sphere - always comes naturally. Ensuring proper consultation and information sharing can be a prob- 
lem even in the smallest of communities, and these may demand just as much attention to the correct design of security governance as nations of larger size (Newton 1982; Bailes 2008). As work begins on an official action plan following parliament's approval of the report, it will be imperative to pay special attention to these practical challenges, as well as maintaining transparency in all further steps. The excellent English version of the report offers a good foundation for seeking international publicity, support and understanding: small players always benefit from presenting their ideas in an accessible world language. But Faroese diplomacy will have much to do in pursuing the complex external implications, not least those involving Copenhagen.

Perhaps the most interesting and delicate point in a final assessment is the role the report plays, and still could play, in the Faroe Islands' constitutional evolution. We have seen that the issues covered in it already lie largely within Faroese competence and have been under deliberate study in Tórshavn for at least five years now. The recommendations, however, break considerable new ground both in the translation of Faroese internal competences into their external dimension, and the translation of external competences into independent policy formulation, separate representation, action and asset acquisition. Fully realizable or not, this is a remarkable programme to be formulated under a government that came to power wanting to turn the clock backwards on home rule. Whether it presages a change of political wind on the latter issue may be too early to say; but it does suggest that 'life itself' in the modern Arctic is pushing towards more independent strategy formulation in the Faroe Islands, as well as in the more prominent and well-documented case of Greenland. ${ }^{19}$

\section{Notes}

1 Canada, Denmark, Norway, the Russian Federation and the US - all having substantial territories above the Arctic Circle - held two separate high-level meetings in 2008 and 2011 of which the first was hosted by the Danes, at Ilulissat in Greenland.

2 The members had a predominantly economic/sectoral background: one from the Faroese research council, two from the fisheries/maritime sector, and three representing other aspects of industry including oil exploration. The secretariat was provided by foreign affairs staff in the PM's Office.

3 For a brief exposition of these theories and an example of their application in novel contexts see (Bailes et al. 2013).

4 Information on this project including summaries of the main workshops is available at http://ams. hi.is/node/363 (accessed 8 December 2013). See also Jákupsstovu and Berg (2012) for relevant findings on the Faroes.

5 For summaries of these and other theoretical approaches the reader is directed to (Williams 2013).

6 See note $i$ above: text of the Ilulissat Declaration is available at http://www.oceanlaw.org/downloads/arctic/Ilulissat_Declaration.pdf (accessed 6 September 2013). The report also has a passage defending the Arctic Council against critics of its effectiveness.

7 See e.g. Nunatsiaq Online news service, 'Greenland's premier boycotts the Arctic Council in "drastic" protest’, 15 May 2013, available at http:/ / www.nunatsiaqonline.ca/stories/article/65674greenland_ walks_away_from_the_arctic_council/ (accessed 22 October 2013).

8 On the West Nordic Council see http://www.vestnordisk.is/id/1450 and Hovgaard et al. (2013). At the WNC's August 2013 meeting in Narsarssuaq it was agreed to start development of some joint guidelines on Arctic policy. 
9 This was set up in 2002 when the first NCM Arctic cooperation programme was launched, see http://arcticportal.org/old-news/621-nordic-council-of-ministers (accessed 7 September 2013).

10 See http://www.arcticparl.org/.

11 The Faroes have opted out of Denmark's EU membership and deal when necessary - eg on fisheries - 'bilaterally' with the EU authorities. In May 2010 the Foreign Minister published the report of a review of possible options for different statuses vis-a-vis the Union (FØROYAR OG ES - møguleikar og avbjóðingar í framtíðar samstarv) available at http://www.tinganes.fo/logir/alit/2010.05\%20 Føroyar\%20og\%20ES\%20-\%20møguleikar\%20og\%20avbjóðingar\%201\%20framtíðar\%20samstarvi.pdf (accessed 21 October2013), but the conclusion was to avoid any change for the present.

12 The reorganization was based on recommendations from a joint Danish, Faroese and Greenlandic report of 2011: http://www.fmn.dk/nyheder/Documents/Rapport_vedr_placering_af_Værnsfaelles_Arktisk_Kommando.pdf. On the opening of the joint command in 2012, see http://www. fmn.dk/nyheder/Arkiv/2012/Pages/EtmerefleksibeltogdynamiskforsvariArktis.aspx

13 The latest EU policy document is a report of June 2012 from the Commission and CFSP High Representative proposing an update of EU Arctic Strategy: see (European Commission 2012).

14 See http://www.neafc.org/.

15 Advocates of an Arctic Treaty generally wish it to include a ban on new resources exploitation including fisheries. Others, including the EU, have mooted a moratorium pending better research, but Russia and Norway are reluctant. The idea of a new fisheries management group is supported by the US and acceptable to most neighbouring states.

16 See http://www.uarctic.org/Frontpage.aspx?m=3.

17 See http://library.arcticportal.org/1474/.

18 As an example of de-bunking see Keil (2013).

19 The present Home Rule Government of Greenland led by PM Aleqa Hammond has declared a clear intention to pave the way for full independence, based on concerns and hopes that are intimately linked with Arctic development. See for example the speech given by Ms Hammond at the 'Arctic Circle' conference in Reykjavik on 12 October 2013, available at http://naalakkersuisut.gl/ /media/Nanoq/Files/Pressemeddelelser/ARCTIC\%20CIRCLE\%20presentation\%20 FINAL\%20EN.pdf (accessed 22 October 2013).

\section{References}

Althingi (Icelandic Parliament) (2011). A Parliamentary Resolution on Iceland's Arctic Policy. Approved at the $139^{\text {th }}$ legislative session. March 28, 2011.

Arctic Council (2011). Agreement on Cooperation in Aeronautical and Maritime Search and Rescue in the Arctic, signed at the Nuuk Ministerial meeting 12 May 2011, available at http://library.arcticportal. org/1474/ ( accessed 7 September 2013).

Arctic Council (2013). Agreement on cooperation on marine oil pollution, preparedness and response in the Arctic, signed at the Kiruna Ministerial meeting 14-15 May, available at http://www.arctic-council.org/ index.php/en/document-archive/category/425-main-documents-from-kiruna-ministerial-meeting (accessed 7 September 2013).

Bailes, Alyson J.K. (2008). Does a Small State need a Strategy? Occasional Paper of the Centre for Small State Studies, University of Iceland, available at http://stofnanir.hi.is/sites/files/ams/Bailes_Final_1. pdf (accessed 21 October 2013).

Bailes, Alyson J.K. (2013). Small Nations in the Wider Arctic Space: Their challenges, options and contributions. Paper for the Polar Law Forum, Akureyri, October 2013.

Bailes, Alyson J.K. and Lassi Heininen (2012). Strategy Papers on the Arctic or High North: A comparative analysis. Reykjavik: University of Iceland Centre for Small State Studies, available at http://ams. hi.is/sites/ams.hi.is/files/strategy_papers_-_pdf_-_singlepage.pdf(accessed 7 September 2013).

Bailes, Alyson J.K. and Baldur Thorhallsson (2012). 'Instrumentalizing the European Union in Small State Strategies', Journal of European Integration, Journal of European Integration, 35(2): 99-115. 


\section{STJÓRNMÁL \& STJÓRNSÝSLA}

Bailes, Alyson J.K, Baldur Thorhallsson and Rachael Lorna Johnstone (2013). 'Scotland as an Independent Small State: Where would it seek shelter?' in Stjórnmál og Stjórnsísla, June 2013 edition, available at http://www.stjornmalogstjornsysla.is/wp-content/uploads/2013/06/a.2013.9.1.1.pdf (accessed 6 September 2013)

Bailes, Alyson J.K., Baldur Thorhallsson and Jean-Marc Rickli (2014). 'Small States, Survival and Strategy' in Archer, Clive, Alyson J.K. Bailes and Anders Wivel (eds.), Small States in International Security: Europe and Beyond. London: Routledge, forthcoming Spring 2014.

Bartmann, Barry (1999). 'The Microstate Experience: Very Small States in the International System', (Smátjóðir við fullveldi) in Hvítabok (The White Book), Tórshavn: Føroya Landstýri, September, 1999, pp.72-91, available at http://www.tinganes.fo/logir/alit/1999.07\%20 Hv\%C3\%ADtab\%C3\%B3k\%20h\%C3\%B8vu\%C3\%B0sbind.pdf (accessed 10 December 2013).

Briguglio, Lino, Gordon Cordina and Eliawony J. Kisanga, E.J. (2006). 'Introduction', in Briguglio, Lino, Gordon Cordina and Eliawony J. Kisanga (eds) Building the Economic Resilience of Small States, Malta: Formatek for the Islands and Small States Institute of the University of Malta and the Commonwealth Secretariat.

Dahl, Robert A. and Edward R. Tufte (1973). Size and Democracy. Stanford, California, Stanford University Press.

Denmark, Greenland and the Faroe Islands (2011). Kingdom of Denmark

Strategy for the Arctic 2011-2020. Available at http://um.dk/en/ /media/UM/English-site/Documents/Politics-and-diplomacy/Arktis_Rapport_UK_210x270_Final_Web.ashx (accessed 6 September 2013)

Den nordiske solidaritetserklæringen (April 2011), available at www.regjeringen.no/upload/UD/ Vedlegg/Nordisk\%20samarbeid/Den_nordiske_solidaritetserklaeringen.pdf (accessed 6 October 2012)

European Commission (2012). Developing a European Union Policy towards the Arctic region: progress since 2008 and next steps. Brussels, 26 June 2012: available at http://eeas.europa.eu/arctic_region/docs/ join_2012_19.pdf (accessed 7 September 2013).

Handel, Michael (1981). Weak States in the International System, London: Frank Cass.

Hovgaard, Gestur, Beinta í Jákupsstovu and Hans Andrias Sølvará (eds.) (2103). Vestnorden - Nye roller i det internationale samfund (West Norden - New roles in international society). Tórshavn: Fróðskapur - Faroe University Press, forthcoming.

Jákupsstovu, Beinta í and Regin Berg (2012). 'The Faroes Islands' Security Policy in a Process of Devolution', Stjórnmál og Stjornsýsla Vol. 8(2), pp. 413.30, available at http://skemman.is/item/view/1946 /14872;jsessionid=EA937C771A38052FB2931EF30CEAF463 (accessed 7 September 2013).

Katzenstein, Peter J. (1984). Corporatism and Change: Austria, Switzerland, and the

Politics of Industry, Ithaca and London: Cornell University Press.

Katzenstein, Peter J. (1985). Small States in World Markets: Industrial Policy in Europe, Ithaca and London: Cornell University Press.

Keil, Kathrin (2013). 'The Questionable Arctic Bonanza - Exaggerated Hopes and False Images of the Arctic as "Prime Real Estate", The Arctic Institute, September 2012, available at http://www. thearcticinstitute.org/2013/09/the-questionable-arctic-bonanza.html\#more (accessed 7 September 2013).

Keohane, Robert O. (1969). 'Lilleputians' Dilemmas: Small States in International

Politics', International Organization 23(2): 291-310.

Newton, Kenneth (1973). ' Is Small Really so Beautiful? Is Big Really so Ugly?'. Political Studies, vol. 30.

Ólavsdóttir, Joan, Jens Chr. S. Justinussen and Beinta í Jákupsstovu (2011). 'The New Kid on the Block - Faroese foreign affairs, between hierarchy and network' in Baldersheim, Harald, Are Vegard Haug and Morten Øgard (eds.), The Rise of the networking region : the challenges of regional collaboration in a globalized world. London: Ashgate 2011. 


\section{STJÓRNSÝSLA}

Prime Minister's office (Faroes) (2013). The Faroe Islands - A Nation in the Arctic. Tórshavn, available at http://www.mfa.fo/Default.aspx?ID=13607 (accessed 6 September 2013).

Simpson, Archie W. (2014). 'The Security of the European Micro-States' in Archer, Clive, Alyson J.K. Bailes and Anders Wivel (eds.), Small States in International Security: Europe and Beyond. London: Routledge, forthcoming Spring 2014.

Stringer, Kevin D. (2013). Sovereign Liecbtenstein: The Soft Power Projection of a Very Small State. Occasional Paper of the Centre for Small State Studies, University of Iceland, available at http://ams.hi.is/ sites/ams.hi.is/files/liechtenstein_layout_final.pdf (accessed 8 December 2013).

Thór, Jón Th., Daniel Thorleifsen, Andras Mortensen and Ole Marquardt (eds.) (2012). Naboer I Nordatlanten: Faroerne, Island og Gronland. Hovedlinjer $i$ Vestnordens bistorie gennem 1000 àr North Atlantic neighbours: the Faroes, Iceland and Greenland. Main themes in 1000 years of West Nordic history). Tórshavn: Fróðskapur - Faroe University Press,

Uttanríkisráðið (Faroese Foreign Ministry, Deild fyri hav og umhvørvi) (2010). Foroyar og samstarvið $i$ Arktis. Stodulysing (The Faroes and cooperation in the Arctic. Situation report), May 2010.

Uttanríkisráðið (Faroese Foreign Ministry, Havtilfeingi, handil og økissamstarv) (2011). Foroyar og samstarvid i Arktis. Stodulysing (The Faroes and cooperation in the Arctic. Situation report), Revised version May 2011.

Vital, David (1967). The Inequality of States: A Study of Small Powers in International Relations. Oxford: Clarendon Press.

Williams, Paul (ed.) (2013) Security Studies: An Introduction (2nd edn), London: Routledge

Wivel, Anders (2005). 'The Security Challenge of Small EU Member States: Interests, Identity and the Development of the EU as a Security Actor', Journal of Common Market Studies Vol. 43/2: 393-412 